УДК: $72.033 ; 82(091)$

ББК: 63.3(0)4; 83.3(0)4; 85.11

A43

DOI: $10.18688 /$ aal $177-2-23$

Fanny Vitto

\title{
The Origin of the Iconostasis in Early Christian Churches in The Holy Land
}

One of the most notable features of the interior of Eastern Orthodox churches is an iconostasis which is a screen that separates the inner sanctuary containing the altar area reserved for the clergy from the nave occupied by the laity. A full iconostasis is a solid wall made of several tiers, entirely obscuring the sanctuary from the view of the congregation standing in the nave. This is in total contrast to Early Byzantine churches where the congregation had a full view of the liturgical activity of the clergy.

In its present form, the iconostasis is of relatively recent origin, the product of evolution in design and liturgical function throughout the history of the Church. The precursor of the iconostasis is a low screen, about waist-high, which encloses the altar area (also called hierateion/sanctuary or presbyterion/presbytery) in Early Byzantine churches. A chancel screen (or a chancel barrier) symbolically indicates the limits of the altar area but does not exclude the faithful, standing in the nave, from the full view of the clergy celebrating what Procopius calls the "mysteries in worship of God" and Paul the Silentiary "the bloodless sacrifice" [33, p. 122]. In early churches the visual access is actually improved, the chancel area being often on a higher level than the rest of a church.

We examine here how and when the low chancel screen of Early Byzantine churches developed into such a prominent iconostasis in Eastern Orthodox churches.

The origin of the chancel screen separating the altar from the nave has been explained in different ways. Its primary purpose was practical, to control the laity from entering the altar area. Several ancient sources describe the congregation in the nave crowding up to the enclosure to see better the rituals occuring on the altar [33, pp. 123-125]. The Christian edifice serving as a church emerged out of its pagan antecedents. In any large public building some kind of barrier is necessary to separate ordinary people from official dignitaries. Such barriers were used in antiquity to protect the emperor from the crowd on public occasions; for example, a low reticulated screen setting off the emperor from the crowd is visible on the base of the $4^{\text {th }}$ century obelisk of Theodosius I in the Hippodrome of Constantinople [48, p.253, pl. 1; 14, p. 108, fig. 2]. Early $20^{\text {th }}$ century theories claimed that chancel screens copy the scaenae frons of ancient theatres $[25 ; 10$, p. 51], but later research has shown that the closing-off of the altar area with a high barrier is a later, medieval development [33, p. 168]. A more plausible theory is that the model of the chancel screen is the Temple in Jerusalem, with the Holy of Holies separated by a curtain, the Veil of the Temple, to which only the High Priest had access [9]. 
The Church Fathers provide descriptions of Early Byzantine chancel barriers, saying that they were made of marble, metal, or wood. In The Ecclesiastical History [17, X. iv.44] written between 311 and 324 AD, Eusebius tells us of a church at Tyre built in the days of Constantine, which has "a fence of wooden lattice-work." According to the ekphrasis delivered by Paul the Silentiary in January 563 AD, in which he describes the Church of Haghia Sophia in Constantinople restored by Justinian, the chancel screen of the church is said to be of "silver" - most likely bronze sheathed with silver [49, pp. 1, 7]. A few wooden barriers have survived in Egypt [7; 19, pp.125-126, 421], but no screen panels covered with precious metal were preserved. However, dozens of chancel screen panels made of marble or limestone were discovered in churches located mostly in the provinces of Palaestina, southern Phoenicia and Arabia (today Israel, Lebanon, Jordan, Syria), also in Egypt, Constantinople, Asia Minor, Greece, and Dalmatia $[7 ; 40]$. They show that chancel screens consist of rectangular panels (cancelli or kankelloi) which are held upright by fixed square posts (stipites).

In most cases, the uppermost step of the altar area has square sockets and grooves for the installation of chancel screen posts and panels. Vertical grooves run along the sides of chancel posts for the insertion of panels. Chancel posts are between $1 \mathrm{~m}$ and $1.20 \mathrm{~m}$ high, square in section and often crowned by a pine cone which is sometimes decorated with a cross, e.g. in Bethlehem [5, p. 239, fig. 113], Mount Nebo [2, pp.503-504 (84)], and Khirbet al-Kursi near Amman [35, p. 51 (359)]. Most chancel posts are decorated with concentric frames, e.g. at Mampsis [37, p. 105, fig. 11:190, 196], Pella [43, pl.20: D, E], Magen [22, figs. 2, 4], and Mount Nebo $[2$, pp. 503-504 $(86,95,97,98)]$. Some of them have an interlacing vine or ivy tendril rising from an amphora, e.g. at Beth Jibrin [22, p. 107, fig. 3.3] and Nahariyah [15, p. 32, fig. 14]; and a few have plant or geometrical motifs, e.g. lilies at Mampsis [37, p. 101, photo 113], an acanthus leaf at Mount Nebo [2, pp.503-504 $(84,85)]$, or a guilloche in a church south of the Temple Mount in Jerusalem [39, pp. 148-150].

Chancel screens, about $1 \mathrm{~m}$ high, are usually carved on the side facing the audience. They have a number of motifs that recur with only minor variations. The most common motif is a cross. It could be a Latin cross represented alone, e.g. at Magen [45, p. 6, fig. 8; 22, fig. 4] and Pella [43, p. 121, fig. 33 bottom]; or within a circle, e.g. at Ostracina [22, fig. 5]. It could also be a Maltese cross within a circle, e.g. at Horvat Bata-Carmiel [47], or within a wreath, e.g. at Hippos-Sussita [36, p. 207, fig. 279 a-b]. Sometimes the letters alpha and omega appear between the arms of the cross, e.g. in Beth Shean-Scythopolis [26, p. 55].

A frequent motif is the stephanostaurion (also called "crown-crosses lemnisci" [1, p. 296; 2, p. 515]), usually a Maltese cross within a laurel wreath, sometimes with a fleur-de-lis depicted between the arms of a cross, and at the bottom are ribbons or tendrils ending in ivy leaves, e.g. in the church of the Monastery of Kyria Maria in Beth Shean-Scythopolis [21, p. 125, fig. 67]. In a slightly more complex version of this motif, the ribbon turns up crowned by a Latin cross, e.g. at Mampsis [21, p. 126, fig 69; 37, p. 93, fig. 9:198], Mount Nebo [2, pp. 514-515 (125)], the Church of St. Lot at Deir 'Ain 'Abata [31, pp.337, 342, fig. 693]; or the ribbons diverge, one turning down with an ivy leaf at the end and the other turning up crowned by a Latin cross (Fig. 1), e.g. at Massuot Yizhaq near Ashqelon [21, p.126, fig 70; 22, p.108, fig. 10; 26, p. 72], Nessana [21, p. 125, fig. 68], Khirbet Barqa-Gan Yavne [23, pp.142-143, fig. 13] and Umm al-Rasas-Mayfaah [1, p.299, fig. 22]. There are also small variations in the shape of the cross within 


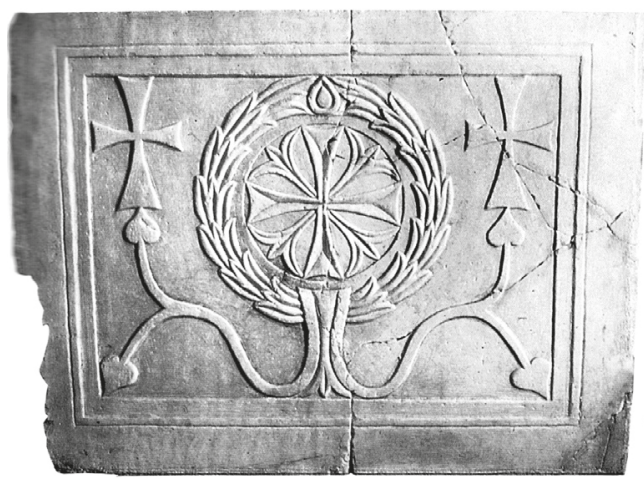

Fig. 1. Chancel screen decorated with a stephanostaurion. Photo by F. Vitto

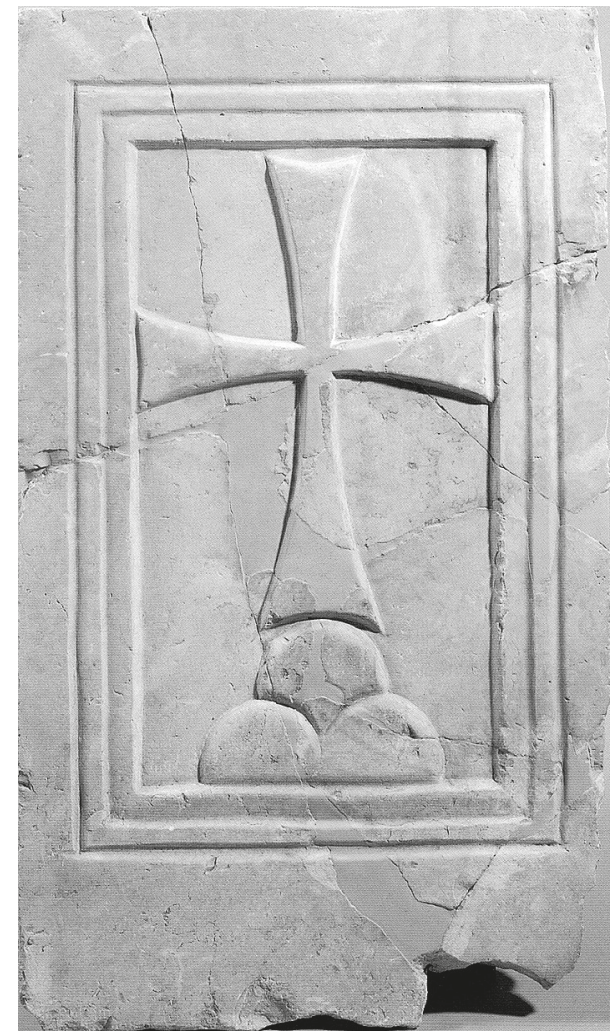

Fig. 2. Chancel screen of the church at Horvat Bata-Carmiel decorated with a Maltese cross standing on 3 semi-circles symbolizing the hill of Golgotha. Photo by F. Vitto the wreath, e.g. at Petra [27] and Rehovot-in-the Negev [38, p. 125, pl.X:46], where the cross has eight arms instead of four. At Ostracina, in North Sinai [22, p. 108, fig. 11] and Horvat Hesheq [21, p. 127, fig. 72], the central cross is replaced by six ivy leaves; and in a church south of the Temple Mount in Jerusalem, the central cross is replaced by a shell [39, pp.135-139]. In the Church of Dominus Flevit on the Mount of Olives in Jerusalem [5, p.240, fig. 114], the motif of the stephanostaurion is repeated twice on the same panel.

Another motif is a cross standing on a circle (the globe?), e.g. at Ostracina [22, p.108, fig.6], or, more frequently, on three semi-circles symbolizing the hill of Golgotha, e.g. at Hippos-Sussita [36, p. 207, fig. 278], Horvat Bata-Carmiel (Fig.2) [26, p.42], Tabgha [6, p.50, fig.3], and Horvat ed-Deir in the Judean Desert [20, p. 126, pl.3]. The three semi-circles are sometimes merged to produce a more realistic rendering of the hill, and the cross is often flanked by animals. These could be sheep, e.g. at Horvat Karkara in Upper Galilee [26, p.73] and Beth Ras-Capitolias [41, photo 27], deer or gazelles, e.g. at Nahariyah [15, p.34, fig. 16]), Horbat Bata-Carmiel [47], the Monastery of St. Catherine in the Sinai [22, p. 108, fig. 8], and in a church south of the Temple Mount in Jerusalem [39, pp. 140-142]. Sometimes the cross is flanked by deer eating a plant sprouting from an amphora bearing a cross [26, p. 70]. Other animals, such as peacocks, e.g. at Shavei Zion [42, pl. XVIIa] and Rehovot-in-the-Negev, where the cross is replaced by the Chi-Rho and flanked by amphorae from which sprout medallions containing grapes and leaves [38, p.113, fig. 170], may also be represented. In a few cases the animals were defaced as a result of iconoclasm, e.g. the pair of sheep flanking a cross at Pel- 
la [43, p. 121, fig. 33 top] and a dolphin on a chancel screen from Hippos-Sussita [4, pp. 121-122, fig. 16.1]. There are also screens with geometric and floral designs, or with an openwork technique [41, photos 28, 29].

A number of screens have Greek inscriptions; for instance, "Procopius donated [the screen] for the sake of his children" at Magen [45, p. 30, fig. 20s], "at the time of Procopios the priest" at Hippos-Sussita [26, p. 73), and "For the sake of Leontis, priest and periodeutes and all his community" at Nahariyah [15, pp. 82-86, fig. 20, pl. XLV].

In the $6^{\text {th }}$ century, chancel screens also begin to appear in synagogues. They are located in front of the bema, where the Torah Shrine or the Ark of the Law is placed, near the wall facing Jerusalem. The reason for their presence in synagogues is not entirely clear, but they certainly served a different function than in churches. Since all the synagogues with chancel screens are located in or near towns with a Christian population, the most plausible explanation is that they were introduced into synagogues in imitation of contemporary Christian practice.

The decoration of chancel screens in synagogues is typical for Jewish iconography; but at the same time, the motifs are very similar to those in churches. The most common motif is a variant of the stephanostau-

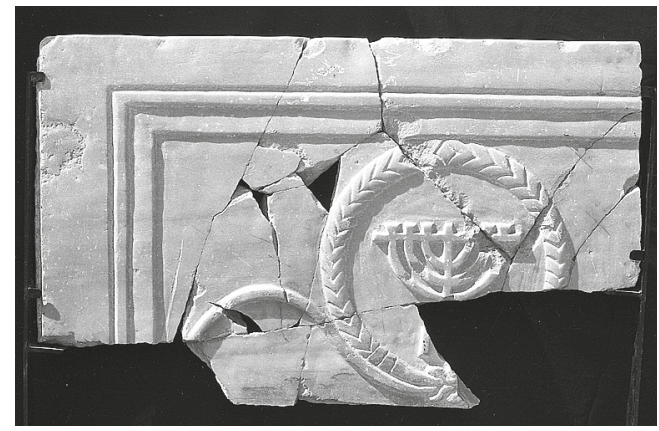

Fig. 3. Chancel screen of the synagogue at Rehov decorated with a seven-branched menorah within a wreath, and at the bottom tendrils ending in ivy leaves. Photo by F. Vitto

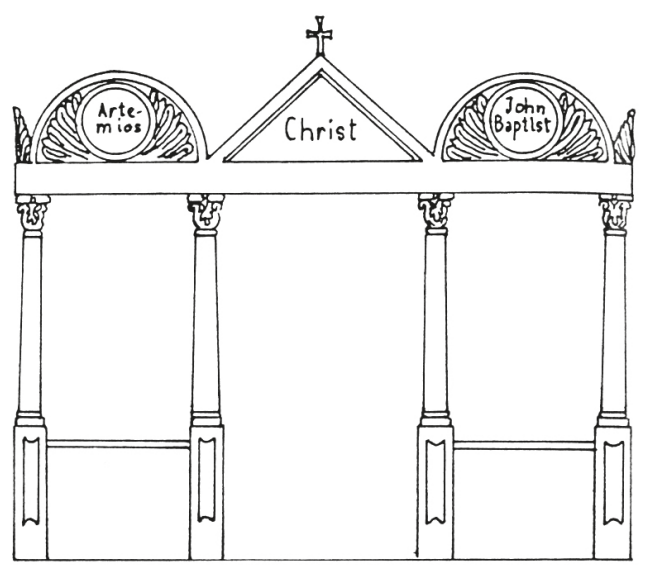

Fig. 4. Reconstruction of the templon in the Martyrion of St. Artemios in Constantinople. Drawing by F. Vitto after Mango: [32] rion with tendrils ending in ivy leaves, with the difference that in synagogues, the cross is replaced by a seven-branched menorah, e.g. at Hammat Gader [21, p. 121, fig. 63], Rehov (Fig. 3) [21, p. 122, fig. 64], and Ashdod [21, p. 121, fig. 62]. On the latter the menorah is flanked by Jewish ritual objects, the shofar (ram's horn) and the lulav (palm branch), and accompanied by an inscription in Greek that says "May there be upon Israel the good and the blessing" and the word shalom in Hebrew script. The similarity of motifs on chancel screens in churches and synagogues suggests that the same workshops were working for both Jews and Christians.

The use of chancel screens continued in the churches of the Byzantine East for many centuries. A further stage in its development is the templon where chancel posts holding chancel panels support colonnettes, upon which an architrave (epistylion) is laid. During the $6^{\text {th }}-7^{\text {th }}$ centuries most churches of the Byzantine Empire continued to have a low, waist-high partition, 
but we learn from literary sources that in Constantinople several $6^{\text {th }}$ century churches already had a barrier with an architrave which ran over the entire chancel screen, e.g. in the Church of Haghia Sophia dedicated in 537 AD [49, p. 23, fig. 33], in the Martyrion of St. Artemios in the Church of St. John the Baptist in Oxeia [32, p.43, fig. 2], and probably in the Church of Polyeuktos completed in $527 \mathrm{AD}$ [24, pp. 136, fig. H, 146-148]. In these churches, the architrave was decorated with sacred images: at Haghia Sophia, with medallions bearing Christ, the Virgin, angels, apostles and prophets while monograms of Justinian and Theodora appeared below, on chancel panels; and in the Martyrion of St. Artemios, with representations of Christ, St. Artemios, and John the Baptist (Fig. 4). Archaeological evidence shows that an architrave resting on colonnettes is also found in a number of $6^{\text {th }}$ and $7^{\text {th }}$ century churches outside Constantinople, but in these churches the architrave was located only above the central door, e.g. in the southern aisle of the northwest church at Hippos-Sussita, Phase IIb, dated to the $7^{\text {th }}$ century [36, p. 207, fig. $279 \mathrm{a}-\mathrm{b}$ ], in the west church at Mampsis [37, pp. 104-106, photo 128, fig. 11:189-190], and perhaps in a few churches located in present-day Jordan [35, pp. 52-53].

Chancel barriers with an architrave (templa) gradually replaced waist-high chancel screens and became the common type of barriers separating the altar area from the nave in the $10^{\text {th }}$ century onwards, especially in Greece and Asia Minor, e.g. in the mid-10 ${ }^{\text {th }}-$ mid- $11^{\text {th }}$ century church at Xanthos, in the $11^{\text {th }}$ century katholikon of the Monastery of Hosios Loukas, and in the katholikon of several monasteries of Mount Athos where this type of a chancel barrier with an architrave has been preserved behind a high iconostasis added later [10; 29, pp. 127-135; 44].

There is no consensus among scholars whether curtains were drawn in the intercolumnar spaces of the templon, or when wooden icons began to be inserted in these spaces. Some scholars claim that in the $11^{\text {th }}$ century, curtains were shut in the intercolumnar spaces to conceal the altar area at certain moments of the liturgy [28, pp. 36, 39], but both Matthews [33, p. 163-171; 34, p. 126] and Bortoli-Doucet [8, p. 44] contend that this is not substantiated by archaeological and liturgical evidence and the liturgy remained perfectly visible for the faithful. Chatzidakis [12], followed by Mango [32, p.40], is of the opinion that icons were already introduced in the intercolumnar spaces in the $11^{\text {th }}$ century, but Lazarev [29, pp. 130-136] believes that in Russia these spaces remained free of icons until the $14^{\text {th }}$ century. Holy personages were represented on the templa of the $11^{\text {th }}-13^{\text {th }}$ centuries, but these were placed on the columns flanking the templon (generally made of fresco or mosaic), or painted on small wooden icons which were set upon the top of the architrave $[11 ; 13 ; 16$, pp. $2-10 ; 3$, p. 353]. This apparently continued to be so in most of the churches of the $13^{\text {th }}$ and $14^{\text {th }}$ centuries, e.g. the $13^{\text {th }}$ century templon of the south Church of the Pantocrator (Zeyrek Camii) at Constantinople [16, p.4, fig. 1; 14, p. 109, fig. 4]. Even in the early $15^{\text {th }}$ century, the description by Symeon of Thessaloniki of a templon decorated with figures of Christ, the Virgin, John the Baptist, angels, archangels, saints, and apostles would refer to the architrave, according to Lazarev [29, pp. 135-140], or to the columns flanking the door of the templon, according to Walter [48, pp. 251, 266].

In the late $14^{\text {th }}$ and $15^{\text {th }}$ centuries, the icons, particularly those executed in Russia, grew in size and the transparency of the early chancel barriers became gradually more and more opaque. The last evolution, the creation of a solid screen which totally cuts off the sanctuary from the nave and prevents the faithful from glimpsing at sacerdotal proceedings behind the screen, became standard in the $15^{\text {th }}$ century in Russia. It is generally held that the templon was 
borrowed from the Byzantines by the Russians, i.e. the barrier with an architrave including its decoration with the Deisis and the festivals. High iconostases with large icons certainly developed in Russia in the late $14^{\text {th }}$ and $15^{\text {th }}$ centuries and probably spread thence to Mount Athos, and further to Greece and the Balkans [29, pp. 142-143; 48, p. 252].

Several theories have been proposed to explain why the low chancel screens of Early Byzantine churches developed in Russia into such a prominent wall that separates visually as well as physically the congregation in the nave from the clergy in the sanctuary. Most scholars agree that this is due to a combination of cultural and theological factors. The impulse of the Hesychast spirituality in the $14^{\text {th }}$ century favoured the contemplation and veneration of icons. Since the mystery of the Eucharist was hidden from the faithful, they were bound to visualize the liturgical symbolism of icons forming the iconostasis [8; 14, pp. 114-115; 46; 3, pp. 340-341; 48, p.266]. The transformation from an open sanctuary barrier to a closed one reflects the change in orientation within the liturgy of the $14^{\text {th }}$ and $15^{\text {th }}$ centuries, and the architecture of Byzantine churches was modified accordingly [14, pp. 113-114]. This change encouraged a type of private piety that was best served by large-scale images. "Laymen and women of this period sought new visual images to satisfy their devotional practices" [18, p. 157]. In the Early Byzantine churches, the liturgy was a liturgy of processions and the focus of attention was on the altar in the apse where the priest was celebrating the mysteries, while in the medieval church, processions had been curtailed and the focus of attention was now on the door of the sanctuary and in front of it, where the clergy made a series of appearances from behind the iconostasis and then returned back into the sanctuary. It was an alternation of concealment and revelation which required a high barrier [34, pp. 125-126]. The late $14^{\text {th }}$ and $15^{\text {th }}$ centuries, during which the Russian iconostasis became higher and higher, is the time when the famous icon painters such as Theophanes the Greek, Prochor of Gorodets and Andrei Rublyov [30; 28, pp. 68-92] lived. There was an abundance of wood in and around Moscow and Novgorod which these great painters could use. Instead of the portraits depicted on earlier icons, they painted full-length figures on icons of monumental proportions. These icons were placed in the churches of Novgorod and Moscow creating a high solid wall which dominated the church interior by its richly painted decoration. The appearance of an iconostasis coincided also with the increased importance and material prosperity of Moscow at that time [28, p. 52]. The trend to enlarge the iconostasis continued not only in the $15^{\text {th }}$ and $16^{\text {th }}$ centuries but also in the $17^{\text {th }}$ century, when additional tiers were put at the top of an iconostasis. At its highest point of development, Russian iconostases became as high as the ceiling and completely filled the archway of the apse. Over the centuries, a few protests were heard against the high barriers, notably in the $16^{\text {th }}$ century during the 'Heresy of the Judaizers' and in the $19^{\text {th }}$ century initiated by John of Kronstadt, but to no avail [8]. A high iconostasis remained the standard in Russian Orthodox churches.

The barrier of a sanctuary has been considerably modified since its origins, but it has kept its original meaning. The Church Fathers already explained that the separation of the space between altar and nave is the symbol of the division between holy and profane, heaven and earth, divine and human. As Bortoli-Doucet $[8$, p. 60] notes "The high iconostasis has an additional significance. It is not only a separation; it is a link between earth and heaven, a link which is visible during the Eucharist. The Russian iconostasis is one of the best testimonies of the spiritual autonomy of Russia which remains at the same time faithful to Byzantium." 


\section{References}

1. Acconci A. Larredo liturgico. Umm al-Rasas, Mayfa'ah. Vol. 1. Gli scavi del complesso di Santo Stefano (SBF Collectio Maior 28). Piccirillo M.; Alliata E. (eds.). Jerusalem, Studium Biblicum Franciscanum Publ., 1994, pp. 290-313 (in Italian).

2. Acconci A. Elements of the Liturgical Furniture. Mount Nebo: New Archaeological Excavations 1967-1997 (SBF Collectio Maior 27). M. Piccirillo; E. Alliata (eds.). Jerusalem, Studium Biblicum Franciscanum Publ., 1998, pp. 468-542.

3. Arida R. M. Another Look at the Solid Iconostasis in the Russian Orthodox Church. St. Vladimir's Theological Quarterly, 2008, no.52, pp. 339-365.

4. Bagatti B. Larcheologia cristiana in Palestina. Florence, G. C. Sansoni Publ., 1962. 283 p. (in Italian).

5. Bagatti B. The Church from the Gentiles in Palestine: History and Archaeology (SBF Collectio Minor 4). Jerusalem, Franciscan Printing Press Publ., 1971. 398 p.

6. Bagatti B.; Testa E. Il Golgota e la Croce: Ricerche storico-archeologiche (SBF Collectio Minor 21). Jerusalem, Franciscan Printing Press, 1978. 161 p. (in Italian).

7. Bolman E.S. Veiling Sanctity in Christian Egypt: Visual and Spatial Solutions. Thresholds of the Sacred: Architectural, Art Historical, Liturgical, and Theological Perspectives on Religious Screens, East and West. S.E. J.Gerstel (ed.). Washington D.C., Dumbarton Oaks Research Library and Collections Publ., 2003, pp. 73-104.

8. Bortoli-Doucet C. L'iconostase et l'espace sacré dans l'église russe aux XIV et XV siècles: doù provient le développement en hauteur de cette iconostase? Le sacré et son inscription dans l'espace à Byzance et en Occident. M. Kaplan (ed.). Paris, Publications de la Sorbonne Publ., 2001, pp. 43-60 (in French).

9. Branham J.R. Penetrating the Sacred: Breaches and Barriers in the Jerusalem Temple. Thresholds of the Sacred: Architectural, Art Historical, Liturgical, and Theological Perspectives on Religious Screens, East and West. S.E. J.Gerstel (ed.). Washington D.C., Dumbarton Oaks Research Library and Collections Publ., 2003, pp.7-24.

10. Bréhier L. Anciennes clôtures de chœur antérieures aux iconostases dans les monastères de l'Athos. Atti del $V$ congresso internazionale di studi bizantini, Roma, 20-26 settembre 1936. Vol.2: Archeologia e storia dell'arte. Liturgia e musica. Rome, Istituto per l'Europa Orientale Publ., 1940, pp. 48-56 (in French).

11. Chatzidakis M. Icônes d'architraves provenant du Mont Athos. Deltion tēs christianikès archaiologikēs hetaireias, 1966, no. 4, pp.377-400 (in Greek, English abstract pp.401-403).

12. Chatzidakis M. Ikonostas. Reallexikon zur byzantinischen Kunt, vol. 3. K. Wessel; M. Restle (eds.). Stuttgart, Anton Hiersemann Publ., 1973, cols. 326-353 (in German).

13. Chatzidakis M. Lévolution de l'icône aux $11^{\mathrm{e}}-13^{\mathrm{e}}$ siècles et la transformation du templon. Actes du XV $V^{e}$ Congrès international d'études byzantines, Athènes, septembre 1976, vol.3. Athens, s.n., 1981, pp. 159-191 (in French).

14. Cheremeteff M. The Transformation of the Russian Sanctuary Barrier and the Role of Theophanes the Greek. The Millenium: Christianity and Russia (AD 988-1988). A.Leong (ed.). Creswood, St. Vladimir's Seminary Press Publ., 1990, pp. 107-124.

15. Dauphin C. (ed.). L’église byzantine de Nahariya (Israël): Étude archéologique (Byzantine Monuments 5). Thessaloniki, Center of Byzantine Studies of the School of Philosophy, Universtiy of Thessaloniki Publ., 1984. 126 p. (in French).

16. Epstein A.W. The Middle Byzantine Sanctuary Barrier Templon or Iconostasis? Journal of the British Archaeological Association, 1981, no. 134, pp. 1-28.

17. Eusebius. The Ecclesiastical History, 2 vols. London; New York, The Loeb Classical Library Publ., 1932.

18. Gerstel S.E.J. An Alternate View of the Late Byzantine Sanctuary Screen. Thresholds of the Sacred: Architectural, Art Historical, Liturgical, and Theological Perspectives on Religious Screens, East and West. S.E. J.Gerstel (ed.). Washington D.C., Dumbarton Oaks Research Library and Collections Publ., 2003, pp. 135-183.

19. Grossmann P. Christiliche Architektur in Ägypten (Handbook of Oriental Studies 1; The Near and Middle East 62). Leiden; Boston; Köln, Brill Publ., 2002. 605 p. (in German).

20. Habas L. The Marble Furniture. The Early Byzantine Monastery at Khirbet ed-Deir in the Judean Desert: The Excavations in 1981-1987 (Qedem 38). Y. Hirschfeld (ed.). Jerusalem, The Hebrew University of Jerusalem Publ., 1999, pp. 119-132. 
21. Habas L. The Bema and Chancel Screen in Synagogues and Their Origin. From Dura to Sepphoris: Studies in Jewish Art and Society in Late Antiquity. L. I. Levine; Z. Weiss (eds.). Portsmouth, Rhode Island Publ., 2000, pp. 111-130.

22. Habas L. The Art of Imported Marble Chancel Screens and Its Influence on Local Production in the Churches of the Provinces of Palaestina and Arabia: A Case Study. SOMA 2008 (Proceedings of the XII Symposium on Mediterranean Archaeology, Eastern Mediterranean University, Famagusta, North Cyprus, 5-8 March 2008) (BAR Int. S. 1909). H. Ozniz (ed.). Oxford, Archaeopress Publ., 2009, pp. 100-108.

23. Habas L. The Mosaic Pavements and Liturgical Furniture of the Church of Bishop John at Khirbet BarqaGan Yavneh. Christ is Here! Studies in Biblical and Christian Archaeology in Memory of Michele Piccirillo, ofm (SBF Collectio Maior 52). L. D. Chrupcala (ed.). Milan, Franciscan Printing Press Publ., 2012, pp. 131-146.

24. Harrison R.M. Excavations at Saraçhane in Istanbul. Vol.1. The Excavations, Structures, Architectural Decoration, Small Finds, Coins, Bones, and Molluscs. Princeton; Washington, Princeton University Press; Dumbarton Oaks Research Library and Collection, 1986. 432 p.

25. Holl K. Die Entstehung der Bilderwand in der griechischen Kirche. Archiv für Religionswissenschaft, 1906, no. 9, pp.365-384 (in German).

26. Israeli Y.; Mevorah D. Cradle of Christianity (Israel Museum Catalogue 438). Jerusalem, Israel Museum Publ., 2000. 232 p.

27. Kanellopoulos C.; Schick R. Marble Furnishings of the Apses and the Bema, Phase V. The Petra Church. Fiema Z.T.; Kanellopoulos C.; Waliszewski T.; Schick R. Amman, American Center of Oriental Research Publ., 2001, pp. 193-213.

28. Labrecque-Pervouchine N. L'iconostase: une évolution historique en Russie. Montreal, Éditions Bellarmin Publ., 1982. 292 p. (in French).

29. Lazarev V. Trois fragments d'épistyles peintes et le templon byzantine. Deltion tēs christianikēs archaiologikēs hetaireias, 1964-1965, no. 4, pp. 117-143 (in French).

30. Lazarev V. N. The Russian Icon: From Its Origins to the Sixteenth Century. Collegeville, Minnesota, Liturgical Press Publ., 1997. 404 p.

31. Loverance R. The Marble and Stone Church Furnishings. Sanctuary of Lot at Deir 'Ain 'Abata in Jordan, Excavations 1988-2003. K.D. Politis. Amman, American Center of Oriental Research Publ., 2012, pp. 337-347.

32. Mango C. On the History of the Templon and the Martyrion of St. Artemios at Constantinople. Zograf, 1979, no. 10 , pp. $40-43$.

33. Matthews T.F. The Early Churches of Constantinople: Architecture and Liturgy. London, University Park, Pennsylvania State University Press Publ., 1971. 194 p.

34. Matthews T. F. "Private" Liturgy in Byzantine Architecture: Toward a Reappraisal. Cahiers archéologiques, 1982, no. 30, pp. 125-138.

35. Michel A. Les églises d’époque byzantine et umayyade de la Jordanie Ve-VIII siècle: typologie architecturale et aménagements liturgiques. Turnhout, Brepols Publ., 2001. 471 p. (in French).

36. Młynarczyk J.; Burdajewicz M. The Northwest Church Complex. Hippos-Sussita of the Decapolis: The First Twelve Seasons of Excavations 2000-2011, vol. 1. A. Segal; M.Eisenberg; J. Młynarczyk; M. Burdajewicz; M. Schuler (eds.). Haifa, The Zinman Institute of Archaeology, University of Haifa Israel Publ., 2013, pp. 194-217.

37. Negev A. The Architecture of Mampsis, Final Report. Vol.2. The Late Roman and Byzantine Periods (Qedem 27). Jerusalem, The Hebrew University of Jerusalem Publ., 1988. 116 p.

38. Patrich J. Architectural Sculpture and Stone Objects. Excavations at Rehovot-in-the-Negev. Vol.1. The Northern Church (Qedem 25). Jerusalem, The Hebrew University of Jerusalem Publ., 1988, pp. 97-133.

39. Peleg O. Decorated Chancel Screen Panels and Posts from the Temple Mount Excavations. The Temple Mount Excavations in Jerusalem 1968-1978 Directed by Benjamin Mazar. Final Report. Vol. 2. The Byzantine and Early Islamic Periods (Qedem 41). Jerusalem, The Hebrew University of Jerusalem Publ., 2003, pp. 135-152.

40. Peschlow U. Dividing Interior Space in Early Byzantine Churches: The Barriers between the Nave and Aisles. Thresholds of the Sacred: Architectural, Art Historical, Liturgical, and Theological Perspectives on Religious Screens, East and West. S. E. J. Gerstel (ed.). Washington D. C., Dumbarton Oaks Research Library and Collections Publ., 2003, pp. 53-71.

41. Piccirillo M. Chiese e mosaici della Giordania settentrionale (SBF Collectio Minor 30). Jerusalem, Franciscan Printing Press Publ., 1981. 124 p. (in Italian). 
42. Prausnitz M. W. Excavations at Shavei Zion: The Early Christian Church. Rome, Centro per le antichità e la storia dell'arte del Vicino Oriente Publ., 1967. 72 p.

43. Smith R.H.; Day L.P. Pella of the Decapolis. Vol.2. Final Report on the College of Wooster. Excavations in Area IX, the Civil Complex, 1979-1985. Wooster, College of Wooster Publ., 1989. 168 p.

44. Sodini J.-P. Une iconostase byzantine à Xanthos. Actes du colloque sur la Lycie antique (Bibliothèque de l'Institut français d'études anatoliennes d'Istanbul XXVII). Paris, Librairie d'Amérique et d'Orient, Adrien Maisonneuve Publ., 1980, pp. 119-148 (in French).

45. Tzaferis V. An Early Christian Church Complex at Magen; Mosaics and Inscriptions from Magen. Bulletin of the American Schools of Oriental Research, 1985, no. 258, pp. 1-32.

46. Velmans T. Le rôle de l'hésychasme dans la peinture murale byzantine du XIVe et XVe siècles. Ritual and Art: Byzantine Essays for Christopher Walter. P. Armstrong (ed.). London, The Pindar Press Publ., 2006, pp. 182-226 (in French).

47. Vitto F. A Byzantine Church Compound and an Oil Plant at Bat as-Sikh (Horvat Bata), Carmiel. Atiqot (in press).

48. Walter J. The Origins of the Iconostasis. Eastern Churches Review, 1970-1971, no. 3, pp. 251-267.

49. Xydis S. G. The Chancel Barrier, Solea, and Ambo of Haghia Sophia. The Art Bulletin, 1947, no. 29, pp. 1-24.

Title. The Origin of the Iconostasis in Early Christian Churches in the Holy Land.

Author. Fanny Vitto - field and research archaeologist. Israel Antiquities Authority; POB 586, Jerusalem 91004, Israel.vitfan1908@gmail.com

Abstract. A typical feature of Eastern Orthodox churches is the iconostasis which separates the inner sanctuary reserved to the clergy from the nave occupied by the laity, preventing the faithful from glimpsing at the sacerdotal proceedings behind the screen. In its present form, it is of relatively recent origin, the product of an evolution in design and liturgical function throughout the history of the church. The precursor of the iconostasis was a low screen which enclosed the altar area in the early Byzantine churches but did not exclude the worshippers from a full view of the clergy celebrating. Dozens of screens made of marble or limestone have been discovered in the provinces of Palaestina, southern Phoenicia and Arabia. They are carved with a number of motifs that recur with only minor variations. Among the most common motifs are the Latin cross, the Maltese cross within a laurel wreath, the stephanostaurion, and a cross standing on three semi-circles symbolising the hillock of Golgotha. The latter is sometimes flanked by a pair of sheep or deer. In the $6^{\text {th }}$ century AD, chancel screens also began to appear in synagogues where they are decorated with Jewish motifs. A further stage in the development of chancel screens in churches is the templon, an architrave at a higher level resting on colonnettes. In Russia, the intercolumnar spaces of the templon remained free of icons until the $14^{\text {th }}$ century. Wooden icons began to be inserted in the intercolumnar spaces of the templon in the late $14^{\text {th }}$ and $15^{\text {th }}$ centuries when the great icon painters started to paint full-length figures on icons of monumental proportion. The creation of the iconostasis as a solid wall is due to a combination of cultural and theological factors, including the Hesychast doctrine which favoured the contemplation of icons.

Keywords: iconostasis; chancel screen; Early Byzantine churches; Eastern Orthodox churches.

Сведения об авторе. Витто Фанни - археолог. Израильское управление по делам древностей, РОВ 586, Иерусалим, Израиль, 91004. vitfan1908@gmail.com

Название статьи. Происхождение иконостаса в ранневизантийских храмах Святой Земли.

Аннотация. Одна из характерных особенностей православных церквей - иконостас, отделяющий алтарь, предназначенный для священников, от верующих, находящихся в храме. Развитый иконостас представляет собой сплошную стену из нескольких ярусов, полностью закрывающую алтарь от глаз паствы. В своем нынешнем виде он сформировался достаточно поздно в результате эволюции литургии и ее оформления на протяжении всей истории Церкви. Предшественником иконостаса был низкий парапет, высотой примерно до пояса, ограждавший виму или пресбитерий в ранневизантийских храмах в Святой Земле. Он символически обозначал границы вимы, но не мешал верующим видеть служащих священников. Напротив, обзор был даже лучше, поскольку вима была выше остальных частей храма. Сохранилось несколько описаний этих алтарных преград в творениях Отцов Церкви, а также десятки плит от алтарных преград, найденных на территориях Палестины, южной Финикии и Аравии. Судя по ним, алтарная преграда состояла из прямоугольных плит, обычно мраморных, которые ставились вертикально с помощью квадратных в сечении столбов. Стороны этих плит, обращенные в пространство 
храма, украшались резьбой, в которой с небольшими вариациями повторялись одни и те же мотивы. Среди наиболее распространенных - латинский или мальтийский крест в лавровом венке, с лилиями между перекладинами, а также крест, стоящий на трех полукружиях, которые символизируют холм Голгофы. В последнем случае по сторонам от креста иногда изображалась пара агнцев или оленей. В более поздних храмах на такие парапеты стали иногда ставить колонны, несущие архитрав. Затем интерколумнии между колоннами и парапетом, бывшие изначально открытыми, стали закрываться иконами.

Последним этапом эволюции алтарной преграды стало ее превращение в иконостас - сплошную стену, закрывающую от взглядов верующих таинства, происходящие по ту сторону преграды.

Ключевые слова: иконостас; алтарная преграда; ранневизантийские церкви; православные храмы. 